\title{
The Invisible Indigence of the Homeless
}

\author{
Jaime Luiz Cunha de Souza ${ }^{1}, \&$ Luis Fernando Cardoso e Cardoso ${ }^{1}$ \\ ${ }^{1}$ Graduate Program in Political Science, Institute of Philosophy and Human Sciences (IFCH), Federal University of Pará, \\ Belém, Pará, Brazil. \\ Correspondence: Institute of Philosophy and Human Sciences (IFCH), Federal University of Pará, Belém, Pará state, \\ Brazil, 66075-110.
}

Received: January 4, 2021

doi:10.11114/ijsss.v9i2.5170
Accepted: February 15, $2021 \quad$ Available online: February 23, 2021

URL: https://doi.org/10.11114/ijsss.v9i2.5170

\begin{abstract}
This article analyzes indigence as a social phenomenon and discusses the factors that have contributed to its permanence over time. The study focuses on street people in Belém, Pará state, Brazil, as an expression of indigence and how public authorities have treated the issue. To provide context, we discuss $19^{\text {th }}$ century social hygiene polices and show how attitudes toward the homeless and thus treatment of this group has changed over time. The current homeless situation is related to the effects of neoliberal policies, psychiatric and prison deinstitutionalization processes and changes related to drug use and availability. Perception and treatment of the homeless are based are based on the biased view that these individuals are unproductive citizens or even criminals. Research results show that, while homeless populations have generally increased across the globe, we observe specific traits related to social exclusion tendencies present for centuries at the local level in Belém.
\end{abstract}

Keywords: indigence, homeless people, social exclusion, deinstitutionalization

\section{Introduction}

This article analyzes indigence as a social phenomenon and discusses the factors that have contributed to its permanence over time. The study focuses on street people in Belém, Pará state, Brazil, as an expression of indigence and how public authorities have addressed the problem of homelessness. To provide context, we discuss the social hygiene polices of the 19th century and show how the treatment of the homeless has evolved over time to the present moment. Treatment and practices toward this population today are underwritten by the logic of neoliberalism, by the deinstitutionalization of prisons and psychiatric hospitals and changes related to drug use and availability.

Since the early years of the 21 st century, a wide range of scholars have published works analyzing the condition of homeless people (or street people). Such works address various themes, including: the social inclusion of the homeless, social exclusion and distancing from other members of society, and the need to remove barriers that prevent the effective integration of the homeless into society (Muggleton, 2013; Oh \& Albertson, 2014). Other studies discuss the loss or reconstruction of social networks and initiatives aimed at the reintegration of homeless people into the formal economy and/or informal work situations (i.e., those with no ties to employers, no fixed wages, and no rights to social benefits (Teasdale, 2010).

More recently authors discuss the precariousness of the homeless vis-à-vis contemporary society and its failure to provide this contingent with decent living conditions (Hughes et al., 2017; Wharne, 2015). Special attention has been given to the interface between homelessness and sexual abuse, psychiatric problems, addiction to licit and illicit drugs, and other risky behaviors (Aguas, 2017; Gattis, 2012; Malone et al., 2015). These discussions often incorporate elements of the somewhat controversial vision of researchers who analyze the role of deinstitutionalization policies, specifically psychiatric and prison facilities, and the rise in the number of homeless people. The work of Hignite and Haff (2017) stands out in this regard.

Building from this context, the current article discusses homelessness as a local phenomenon with historical specificities that converges with national and global social phenomena. The latter produce structural changes intensifying homelessness locally, making it practically innocuous to measures designed to ameliorate the situation - precisely because these phenomena fuel the mechanisms that generate destitution and homelessness. 


\section{Indigents: A Secular Issue}

Homeless people have existed in almost all historical periods, most often as a sub-group placed of a more generic category of the poor or indigent. Williams (1973), for example, discusses the English laws designed to prevent the mobility of the poor, restricting them to specific spaces. According to this author, the preamble to the 1662 Poor Laws brought forth a type of complaint:

by reason of some defect in the law, poor people were not restrained from going from one parish to another, and do therefore endeavor to settle themselves in those parishes where there is the best stock, the largest commons or wastes to build cottages and the most woods for them to burn and destroy (Williams, 1973, p. 85).

To restrain the mobility of the poor and contain these individuals, asylums were created, where the sick, elderly, insane and other outcasts were confined and could be more efficiently controlled. According to Williams (1973), from 1693 onwards elderly residents were placed under a local judge's authority who kept their names in a register and appraised them annually. A 1697 law stipulated that the poor should wear a red or blue 'P', allowing them to be recognized as destitute and preventing them from moving beyond legally authorized limits.

Marshall (1967) explains that in the 19th century public authorities, and the society at large, did not know what with social outcasts. Thus, those considered as such were deprived of their rights, restricted of their freedom and their personal reputations were tarnished. The tendency was to group all vagrants, strays, and the elderly into the same generic category of "indigents" and place them in penal institutions. This broad notion of indigence became deeply rooted in the public imagination - as it was reinforced by the state, which perfected its classification and screening instruments. These mechanisms created a legion of poor individuals who fell under public tutelage. Rights of the so-called "indigents" were largely suppressed, a practice justified by the notion that the state was obligated to provide for the needs of this contingent; at the same time, however, indigents did not have the right to demand such provisioning (Góis Junior \& Lovisolo, 2003; Oliveira, 2003).

In the middle of the 19th century, social spaces were reorganized to remove and segregate indigents from the public eye. Notions of social hygiene practices called for confining indigents to institutions, with the expectation that they would be cured through internment. Authorities, and the society at large, justified these measures on the grounds that they were assisting, and not discriminating against the sick or the poor. However, these measures were merely a new version of the old practices of social exclusion and violence so common in previous centuries (Coimbra \& Nascimento, 2005).

In the social imaginary of the 19th century, cities were social and physical spaces that concentrated the dispossessed masses - a situation that created an uncomfortable contrast with the economic development and wealth expansion occurring at this time. Such disparities led to radical changes in how society perceived poverty: the streets and their inhabitants were now seen as dangerous entities, as threats and an attack on hygienic standards and morals. The poor were associated with promiscuity, disease, crime and marginality (Coimbra \& Nascimento, 2005; Venancio, 2004). Thus, initiatives aimed at "sanitizing" cities were based on the establishment and expansion of institutions designed to curb urban poverty and restrain the mobility of the poor. The 19th century asylum took on characteristics similar to those of the 18th century madhouses. However, while the madhouses of the $18^{\text {th }}$ century were institutions characterized by their undifferentiated homogeneous spaces, the latter were comprised of fragmented internal spaces meant to assist groups of individuals with specific characteristics (Foucault, 1999).

According to Cunha (1986), under the framework of degeneracy theory, which was the conceptual base of $19^{\text {th }}$ century social hygiene policies, public authorities were most concerned with cleanliness and maintaining order in urban environments. Maintaining order presented challenges in the context of urban growth, unemployment, precarious housing conditions, difficulties with food provisioning and the increasing numbers of poor people living on the streets. Monitoring indigents became more efficient when the urban areas where they poor concentrated came under direct surveillance.

The creation of specific spaces for different "types" of indigents influenced representations of poverty and indigence in Brazil and, consequently, in Pará state. Signs of these influences are recorded in Lustosa (1992). According to this author, in the middle of the $19^{\text {th }}$ century, the treasurer of the former Grão-Pará Province ${ }^{1}$ provided resources to support the Tucunduba hospital. This institution was founded in 1815 by the Holy House of Mercy (Santa Casa de Misericórdia) as the first institution in the state to house leprosy patients.

Nine years later, in 1824, another institution was founded, the Silver Leper Colony (Leprosário do Prata) also designated to care for leprosy patients. The presence of such an institution indicates the existence of a number of people suffering from this disease in Belém at this time. It also demonstrates public authorities' preoccupation with restraining the movement of this population and segregating them into institutions especially designed for their care. Lustosa (1992) states that those suffering from leprosy were generally abandoned by their relatives and therefore wandered the streets 
as beggars. The author also comments that the same logic of segregation and categorization also led to the creation of orphanages to receive orphaned and neglected girls. These institutions served to remove children from Belem's central areas - actions justified on the grounds that children would be better cared for and protected in these homes.

Mirroring tendencies in Europe and in other regions of Brazil, a series of proposals for the establishment of institutions became part of a major urban restructuring project in Belém at the turn of the 20th century. Public authorities defended these initiatives as the ultimate solution to the problems of crime and indigence in Belém (Miranda et al., 2015). During this period, per the initiative of Antônio Lemos ${ }^{2}$, the Don Macedo Costa Mendicant Asylum (Asilo de Mendicância Dom Macedo Costa) was built. Initially, the asylum was to provide a definitive solution to the problem the visibility indigence. In the years following, this institution was converted to a facility strictly dedicated to elder care.

Furthermore, at the beginning of the 20th century, an orphanage in the city of Outeiro, located in the greater Belém metropolitan area was created (Instituto Orfanológico do Outeiro). According to Pinheiro (2017), the institution was designed to receive orphaned and neglected boys, between five and eight years old, providing them with protection, social assistance and schooling. The institution was run by the state government, and children without parents, or poor children whose parents signed over their rights, came under the care and responsibility of the institution until they completed their education and the institute deemed its mission complete.

However, according to Pacheco (2018), institutionalization only became a legal imperative imposed by the Brazilian state after 1930 through a specific policy, which established the compulsory confinement and isolation of the children of those sick with leprosy. Such children were sent to institutions referred to as preventive/educational facilities (Preventórios/Educandários). Pacheco (2018) states that, at this time, efforts aimed at advancing social progress and civilization were strongly influenced by medical knowledge, guided by eugenics and conceptions of hygiene. Proposals for progress and development were based on ideas of social regeneration and revitalization.

Pacheco (2018) also states that in Pará state, the campaign to combat leprosy resulted in the expansion and improvement of the Tucunduba hospital and the Silver Leper Colony, as well as inauguration of the Marituba Leper Colony in 1939. In 1942, the Educandário Eunice Weaver Colony was inaugurated. The construction of the institution was a joint effort between doctors, representatives of the Pará elite and middle class, politicians, philanthropic institutions and religious entities. This institution operated until 1980 receiving children of leprosy patients.

Little by little, the same notions held by Europeans and present in other regions of Brazil, were adopted locally. According to these beliefs, "indigents" needed to be placed into increasingly specific categories; however, all continued to be marked by the same stigma and suffered from physical, symbolic and psychological forms of violence. Authorities sought to take indigents off the streets - with the use of force if necessary-and to segregate them into specialized institutions that, at the time, were quite far from the center of the city. In this way, their presence would not hurt the sensibility of the elite who enjoyed the luxuries gained through the sale of rubber traded in international markets during what became known as the Amazon "rubber boom" (Marinho et al., 2015; Miranda et al., 2015).

Throughout much of the 20th century, attempts to isolate those who were considered socially undesirable, to remove them from the public eye by placing them in institutions - a form of social control - have remained at the forefront of state actions to deal with this segment of the population. However, social dynamics of the end of the 20th century and the beginning of the 21 st century have revealed the complete failure of this method. Namely, the rapid growth in homelessness, in which the population is made up of men and women of all ages on the street due to diverse circumstances (due to poverty, familiar abandonment and/ drug or alcohol abuse)—illustrate how solutions with implicit or explicit sanitizing objectives have entirely failed.

Recent official publications attest to the magnitude of the homelessness problem in current Brazilian society. A survey conducted in 2009 by the Ministry of Social Development and Hunger Prevention (Ministério do Desenvolvimento Social e Combate à Fome) in the 71 largest Brazilian cities, including state capitals, revealed that there were approximately 32,000 adults (18 years and up) living on the streets. These individuals take shelter on sidewalks, town squares, highways, parks, viaducts, gas stations, beaches, boats, tunnels, depots, abandoned buildings, alleyways, dumps, scrap yards or stay overnight in institutions (hostels, shelters, halfway houses and other support houses and churches). At the time of research, approximately 400 people were living on the streets in Belém (Brasil, 2009). The national SUAS Census in 2013, 2014 and 2015, which surveys 1,924 municipalities in all Brazilian states revealed that approximately 85,000 were people living on the streets (Brasil, 2020).

A publication by the Institute of Applied Economic Research (Instituto de Pesquisa Econômica Aplicada [Ipea]) estimated, that at the time of research, approximately 102,000 people were homeless in Brazil (Natalino, 2016). Two-fifths (40.1\%) pertain to municipalities with more than 900,000 inhabitants and more than three quarters (77.02\%) were registered in large municipalities with more than 100,000 inhabitants. The same publication estimated that in 3,919 smaller municipalities, with up to 10,000 inhabitants, about 7,000 people were living on the streets. Street people 
are thus largely concentrated in more populous municipalities, such that the regional distribution of homeless populations is strongly influenced by the presence of large cities and their surrounding metropolitan regions.

Cortizo (2019) explains that in 2014, the Brazilian economy grew by just 0.5\%; it fell 3.5\% in 2015 and 3.3\% in 2016. In 2017 and 2018, the annual GDP grew again, but timidly, around 1.1\%. According to this author, unemployment almost doubled between 2014 and 2018 (rising from 6.5\% to 12.0\%), directly affecting the Brazil's poorest citizens. Economic distress was reflected in data published in December 2018 from centers that specialize in attending to the homeless (Centros Pop). These centers welcomed 29,223 people, of which $49 \%$ were drug users, $29 \%$ were migrants (coming from other states or countries) and $6 \%$ had mental disabilities. The number of homeless people registered in the Cadastro Único (National register for low-income families) experienced a 16-fold increase: growing from 7368 families in August of 2012, to 119,636 families in March of 2019. Cerqueira and Bueno (2020) show that, between 2017 and 2018 homicide reports against homeless people increased 567\%; in the same period, attempted homicide reports against homeless people increased $250 \%$.

\section{The Irrevocable Exclusion of Those Who Cannot Be Assimilated}

State failure to solve the problem of homelessness can be attributed to the expansion of poverty and its transformation into a chronic condition. In this way, neoliberal policies, which intensified over the last two decades of the 20th century, played an important role in shaping contemporary indigence patterns. Neoliberal policies have hit the most vulnerable the hardest, moving them from a condition of poverty to misery, thus increasing the number of indigents. Waldmann (2006) uses the term "Anomic State" (El Estado Anómico) to describe the situation when the state can no longer coordinate policies to guarantee basic living conditions to its poorest citizens (such they are not guaranteed their basic citizenship rights) Waldmann (2006, p.11) argues that in Latin America, states develop irregular characteristics because their institutions are weakened, making them incapable of ensuring security and well-being for their citizens. In addition, states themselves become drivers of disorder, insecurity and conflict when they are lured by corruption and organized crime.

Efforts to decrease the state resulted in the weakening of democratic institutions. Following Beck (2018), this situation leads a political vacuum, where institutions become incapable of operating; in their place we observe the emergence of parallel and violent systems dominated by state agents, who operate on the fringes of legality. These agents form powerful and lethal entities, such as militias and extermination groups (Carvalho, 2016; Mendonça, 2014; Nunes, 2016).

The failure to address widespread drug use, especially with regard to victims' recovery, creates legions of addicts across the globe. In the poorest countries, increased availability of inexpensive drugs represents both a social tragedy and serious public health problem due to speed with which these substances cause physical and mental degradation. States neglect to care for addicts, while spending fortunes on superfluous wars against trafficking, far too complex for them to control.

According to Naim (2006), when examined on local and global scales, the drug trade and other related criminal activities promote a promiscuous and inseparable relationship between licit and the illicit activities. The drug trade involves small and large businesses, banking systems, exchange offices, and formal and informal networks through which money and power circulate. While hundreds of millions of dollars are spent fighting against drug trafficking with modest results, destitution on the streets caused by compulsive drug use increases. This situation is a clear example of what Baumann (2001) called "zombie institutions", stemming from a combination of corruption, incompetence and lack of accountability. For this author, such institutions have been clinically "dead" for a long time; however, they are not capable of disappearing definitively since those involved insist on carrying out their traditional functions, almost mechanically, even knowing that operations will continue regardless of their presence.

Bauman (2009) comments that the state and its institutions seem to be unable to deal with a world that has changed radically in certain respects: the world has become more volatile, has lost its consistency, human relationships are less tangible, and insecurity and fear are constant. Cities have urbanized at a dizzying speed; most have not been prepared to receive the influx of migrants, who wind up being displaced to cities' outskirts or remain in central areas begging for coins, food or drugs. Thus, urban streets concentrate indigents and governments do not have the competence or political will to find an adqueate solution.

In the context of increasing homelessness, xenophobia also broods. Since 2010, there has been an influx of migrants from Venezuela who now occupy many central areas in Belém. Most have come to Brazil to escape the economic crises occurring in their home country and many come with other family members. Without work perspectives, they have become beggars at traffic lights or adopt other precarious strategies in the licit or illicit economy. Belém residents are often hostile toward this group and sometimes harass them, exercising systematic social and psychological oppression against these migrants. 
The ill treatment of Venezuelans and other poor people that occurs in Belem is common throughout Brazil and other countries in the developing world. In Latin America, urban areas have become a kind of deposit, where the problems created by the acceleration of social exclusion processes accumulate. Homeless people make up a contingent considered "superfluous"- people who have lost all means of sustenance and housing, either by being forced to migrant under precarious conditions, or by the damage caused by drugs, or mental illness, or by a combination of these factors.

On a local level, the homeless in Belém are subject to the same impossibility of integrating into society, as identified by Castells in (2005). In his work, Castells analyzed the consequences of technological development and the restructuring of productive relations on the poor and their possibilities of participating in society. According to this author, begging in contemporary society is not necessarily due a lack of work opportunities, but rather to the new ways in which work is organized. Those with few credentials can only access temporary and/or poorly paid jobs - thus the term os miseráveis (the retched) applies more frequently to those living on the uncertain and shifting line between unemployment and poverty. The constant and growing presence of impoverished people relegated to the streets leads, however, to a certain naturalization of the inhuman conditions to which they are subjected.

In this sense, Santos (2003) explains that at the core the growing number of homeless people and indigents is a form of social apartheid. On the one hand, are groups linked to state power with special rights and on the other are those who are entirely excluded and have no rights. These groups are largely invisible to the state and to passers-by who pay them no mind. Finally, due to to being homeless, they have few prospects of going after their rights and changing their situation. One exemplary example of this invisibility relates to the Brazilian government's COVID-19 relief program for the nation's poorest citizens. Early into the global pandemic, authorities were surprised by the number of people who requested aid. The federal government had planned to provide benefits for 15 to 20 million for the impoverished families but wound up approving benefits for over 65 million people. Thus, over 45 million people living in poverty had previously been ignored by the government - being invisible to the state.

This invisibility is the result of the naturalization of indigence, a type of self-inflicted, selective blindness, grounded in the inability to sympathize with the poor and feel indignation towards their suffering and the violation of their rights (Cardia, 1995). This indifference occurs on various levels but is essentially fed by the omission by the state, which is completely incompetent in carrying out its most elementary function: to protect and assist its citizens.

\section{Discussion: The New Morphology of Indigence}

The growth of the poorest masses and especially in the number of homeless people has taken on a new reconfiguration over the last three decades of the 20th century. These changes have resulted from structural transformations in the capitalist system, which diminished the power of state intervention and shifted state responsibility to private initiatives (Garland, 2008). It can also be linked to the negligence and incompetence of public administrators who abandoned the search for solutions to poverty - exacerbated by the effects of neoliberalism.

In practical terms, this has led to changes in the ways in which state institutions deal with poverty. One of expression of this change is the movement against asylums that began in Brazil in the 1970's (termed the movimento antimanicomial). The movement positioned itself against institutionalization, while defending the need to strengthen social ties between health professionals and society, especially the families of the mentally ill (Lüchmann \& Rodrigues, 2007). According to Lüchmann and Rodrigues (2007), over the course of the 1980s into the 90s, this movement became consolidated and well-articulated, and the anti-asylum perspective had become the new paradigm. In Belém, the milestone of this transition was the deactivation of the Juliano Moreira Psychiatric Hospital in 1984.

This paradigm shift, however, came with adverse results. It became extremely difficult, for instance, for families to take on the role of at-home caregivers. As a consequence, some former patients became homeless, both due to a lack of public support for themselves and their families and to the chronic lack of financial resources. In the 1980s, resources for social programs were limited by economic crises linked to high rates of inflation in Brazil. Social programs were also limited by the absence of the political will to prioritize caring for the mentally ill.

Another factor that had a significant impact on the increase of homeless people was the expansion of drug consumption, a global phenomenon also present in Brazilian cities. The Amazon region, and especially the city of Belém, due to its access by highways to other regions of the Brazil became an important hub for the flow of drugs from Colombia and Peru. These dynamics led to greater local drug availability and consumption (Machado, 1997). The emergence of cheap drugs, accessible even to the poorest segments of the population, generated a number of interpersonal and family conflicts, which further aggravated social vulnerability, especially when drug consumption was linked to mental illness.

According to Naim (2006), in the 1990s, the number of countries that recorded serious problems with drug addiction increased considerably. Furthermore, violent territorial disputes or conflicts due to unpaid drug-related debts increased by the same portion. Since disputes occur in urban spaces, homeless people often become the defenseless victims of 
these dynamics due to their direct or indirect involvement with the drug trade. Homeless people are sometimes intermediaries selling small quantities of drugs, as consumers, or winding up in debt to traffickers.

The spread of crack use has introduced an even more perverse dynamic - due both its tendency to create dependency and for its extremely low cost. Since it is cheap and widely available, homeless people can easily acquire crack and have become important vectors in the drug market - to the point of congregating in specific places known as "cracklands" (cracolândias), present in most large and medium-sized Brazilian cities. The concentration of addicts and suppliers, present at all hours of the day, forms a community of outcasts left to their devices own under the complacent gaze of public authorities (Mata \& Fernandes, 2019). Mata and Fernandes (2019) explain that for individuals who congregate in these spaces, drug use is their primary focus and they live to raise money to feed their addition.

Cracklands and other spaces called "psychotropic territories" (Mata \& Fernandes, 2019, p. 195) are characterized by a constant influx of homeless people. Those without money to purchase crack get involved in a series of informal activities near these spaces, as they wish to remain close by so they can purchase and consume drugs. In Brazil, the homeless often work on city streets helping people park their cars and watching over owners' vehicles while they shop or do other errands. Additionally, begging sometimes leads to conflicts among the homeless who fight for the best and most lucrative begging spots.

Pinho et al. (2012) explain that continual crack use not only affects the consumer but has devastating effects on family structure and dynamics - above all creating distance between the user and his/her family. The user's antisocial behaviors can make preserving the family integrity more difficult. Ramiro et al. (2014) show that crack users usually have a history of childhood mistreatment, live (or have lived) with family members who were users, occupy situations of socioeconomic exclusion and impoverishment and have little schooling. All of these factors contribute to their vulnerability toward becoming drug use. Homeless people also generally come from similar vulnerable backgrounds. Addicts often leave their home environment to live on the streets, where they are exposed to violence, crime, drug abuse and experience constant social discrimination and stigma. According to Day and Paul (2007), while deinstitutionalization and the introduction of cheap drugs, such as crack, contribute the growth in the number of street people, extreme poverty continues to be an important risk factor for homelessness.

For these authors, the social vulnerability of certain segments allows for poverty to develop with more force. Del Monte Madrigal (2019) and Pimenta (2019) also agree that diverse contexts of individual suffering, social disadvantages, and the degradation of structural conditions, which more greatly affect the lower strata of society, play significant roles in the gradual loss of social networks and the material and affective resources, necessary to guarantee survival in dignified conditions. Along the same lines, Magni (2006) affirms that the rupture of familiar and socio-affective ties can lead individuals to a life on the streets and once there they are subjected to stereotypical social representations. Such views tend to categorize street people as either abandoned, as impotent victims, or as intruders who do not fit into the ideal aesthetics of the urban landscape (Medeiros, 2019).

For Day and Paul (2007), the condition of homelessness is a precursor to drug and alcohol abuse - even though experience with these substances usually precedes life on the streets, and often induces the conflicts leading to homelessness. For instance, Del Monte Madrigal's research (2019) shows that subjects generally began to consume drugs long before living on the streets. Add to this a broken family situation and individuals find themselves facing two complementary perspectives - both of which compromise their physical and mental conditions: living on the streets and insertion into the world of licit and illicit drugs (Hignite \& Haff, 2017).

The struggle to survive on the streets both accentuates the deterioration of one's physical and mental state visible through signs of malnourishment and impaired bodily functions and also weakens the ability to change one's condition through one's own initiatives. Pimenta (2019) explains that for many homeless, the decision to go on the street is their own, being related to drugs and alcohol or an attempt to protect their family from the damages that dependence causes. Both the individual and the family suffer as a result of this decision, which then makes drug use a kind of escape valve for day-to-day anguish.

Along with the problems arising from their tragedies, homeless people need to compete for the use of urban spaces. Their concentration in places, such as public squares and parks and the intense flow of people into and out of these spaces, results in conflicts with local residents and street venders (Medeiros, 2019; Pimenta, 2019). From the perspective of Medeiros (2019) and Pimenta (2019), their use of public space tends to pressure state authorities to view the homeless from a biased perspective. Street people are assumed to be dangerous - either being a threat to public safety or seen as destructive of public property. For McNamara (2008), such concerns are reflected in the punitive approach to the homeless situation, which conceives of their behaviors, such as begging or the public drug use, primarily through the lens of criminalization. Furthermore, such conflicts reinforce discourses arguing in favor of the forced institutionalization of homeless people. 
Writing in the context of the United States, McNamara et al. (2013) show that governments generally do not prioritize the issue of homelessness. Homeless people only receive attention when they commit serious crimes or are victimized. In fact, the homeless are particularly vulnerable to criminal victimization and are often victims rather than perpetrators. For Walker and Katz (2008), the homeless problem in the US has become even more complex due to changes in the characteristics of these groups occurring since the early 1990s. In fact, homeless people were once easily identifiable because they were basically made up of the mentally ill or those with drug problems. Similar changes in the homeless population were also seen in Belém, where street people began to include families, children, victims of domestic violence, the unemployed, workers who cannot afford to pay rent, and people previously institutionalized in psychiatric hospitals and correctional institutions.

In Brazil the most visible face of public authority is the police; thus, homelessness is distinctly marked by the stigma of delinquency. From the perspective of the police, the homeless are individuals involved in petty theft or those in debt to traffickers who wind up being victimized for their own acts. The overlapping realities of the drug world and life on the streets often leads homeless to imprisonment. Incarceration exacerbates their condition of marginality in a revolving door from prison to the street back to prison - a repetitive cycle plagued with violence (Pimenta, 2019). Thus, homeless people are constantly pressured by a perverse logic; seen as unproductive people in the economic system and thus expendable, such that if they, die, nobody will miss them.

\section{Conclusion}

Over 200 years have passed since the prominence of the $19^{\text {th }}$ century sanitization policies, which sought to remove homeless people for the public eye. This span of time has been wrought with political and social transformations in Brazil and beyond: world wars, periods of authoritarian rule and democracy, economic oscillations, including periods of high and low inflation, the rise and fall of unemployment. However, through all of this, homelessness has remained a constant challenge to all governments, regardless of their political leanings.

Over the last four decades, the dynamics of a throwaway society, which characterizes the contemporary moment, has consolidated into a norm. More than the disposal material goods, this period is characterized by the discarding of values, lifestyles and stable relationships, often making human subjects into superfluous and expendable bodies. Masses of people, who have no way of being absorbed into the neoliberal logic, paradoxically generates both wealth and poverty - the former concentrated in the hands of an increasingly smaller number of people. Wealth concentration has created more unemployment, producing a contingent of people who will never be assimilated into the productive system. This situation creates indigence and, consequently, the condition of the homelessness is ever-present, representing a threat to innovations in the productive system. In developing-world countries like Brazil, where precarious education and inadequate professional training are the norm, the skills and no-how needed to obtain a steady employment job is unattainable for the majority of the poor, such that the state of indigence is forever lurking.

Being homeless in Brazil is itself a risk factor for death by disease, drug use or involvement with criminality —as either a victor or tormentor. Crimes that affect homeless people have little prominence in police statistics, as data are not reported as crimes inflicted on specific social groups. Therefore, they lose the specificity of the context under which the crime was committed. As a social group, the homeless people are invisible to public authorities; both in life and death: they viewed merely as the indigent.

\section{Acknowledgements}

Our special thanks to the people who, despite the difficulties, agreed to talk with us about their dramas, sufferings and struggles. This strengthened us and inspired us to build this work.

\section{References}

Aguas, H. (2017). Homeless demography in Los Angeles County. In L. Leonard (Ed.). Environmental Criminology: Spatial analysis and regional issues (pp. 69-86). Emerald Publishing Limited. https://doi.org/10.1108/S2051-503020170000020005

Bauman, Z. (2001). Modernidade líquida. Jorge Zahar Editor.

Bauman, Z. (2009). Confiança e medo na cidade. Grupo Companhia das Letras.

Beck, U. (2018). Sociedade de risco mundial: Em busca da segurança perdida. Leya.

Brasil (2009). Ministério do Desenvolvimento Social e Combate à Fome. Rua: Aprendendo a contar: Pesquisa nacional sobre a população em situação de rua. MDS.

Brasil (2020). Ministério da Cidadania. Portal Censo SUAS. Retrieved from https://aplicacoes.mds.gov.br/sagirmps/portal-censo/. 
Cardia, N. (1995). Direitos humanos e exclusão moral. Sociedade e Estado, 10(2), 343-389.

Carvalho, C. C. A. (2016). O justiçamento coletivo e a violação dos direitos humanos no Estado democrático de direitos. PÓLEMOS, 5(9-10), 97-114.

Castells, M. (2005). A sociedade em rede. Paz e Terra.

Cerqueira, D., \& Bueno, S. (Org.) (2020). Atlas da violência 2020. Ipea. Retrieved from https://forumseguranca.org.br/wp-content/uploads/2020/08/atlas-da-violencia-2020.pdf

Coimbra, C. M. B., \& Nascimento, M. L. do (2005). Ser jovem, ser pobre é ser perigoso? JOVENes: Revista de Estudios sobre Juventud, 9(22), 338-355.

Cortizo, R. M. (2019). População em situação de rua no Brasil: o que os dados revelam? Ministério de Cidadania. Retrieved from https://aplicacoes.mds.gov.br/sagirmps/ferramentas/docs/Monitoramento_SAGI_Populacao_situacao_rua.pdf

Cunha, M. C. P. (1986). O espelho do mundo: Juquery, a história de um asilo. Paz e Terra.

Day, C., \& Paul, C. (2007). Protecting young people from homelessness and escalating drug and alcohol use. Housing, Care and Support, 10(2), 15-22. https://doi.org/10.1108/14608790200700010

Del Monte Madrigal, J. A. (2019). Devenir habitante de calle en una ciudad fronteriza del norte de México: Deportación, consumo de drogas y violencias. Civitas: Revista de Ciências Sociais, 19(1), 159-177. https://doi.org/10.15448/1984-7289.2019.1.30700

Foucault, M. (1999). Em defesa da sociedade: Curso no Collège de France (1975-1976). Martins Fontes.

Garland, D. (2008). A cultura do controle: Crime e ordem social na sociedade contemporânea. Revan, Instituto Carioca de Criminologia.

Gattis, M. N. (2012). Overrepresentation and disparate outcomes: Examining health disparities based on sexual orientation in the context of homeless youths. In S. R. Notaro (Ed.). Health disparities among under-served populations: Implications for research, policy and praxis (pp. 207-224). Emerald Group Publishing Limited. https://doi.org/10.1108/S1479-358X(2012)0000009013

Góis, J. E., \& Lovisolo, H. R. (2003). Descontinuidades e continuidades do movimento higienista no Brasil do século XX. Revista Brasileira de Ciências do Esporte, 25(1), 41-54.

Hignite, L. R., \& Haff, D. R. (2017). Rapid rehousing of formerly homeless jail and prison inmates. Housing, Care and Support, 20(4), 137-151. https://doi.org/10.1108/HCS-06-2017-0015

Hughes, C., Madoc-Jones, I., Parry, O., \& Dubberley, S. (2017). A place to call our own: Perspectives on the geographical and social marginalisation of homeless people. The Journal of Adult Protection, 19(3), 105-116. https://doi.org/10.1108/JAP-09-2016-0022

Lüchmann, L. H. H., \& Rodrigues, J. (2007). O movimento antimanicomial no Brasil. Ciência \& Saúde Coletiva, 12(2), 399-407. https://doi.org/10.1590/S1413-81232007000200016

Lustosa, A. (1992). Dom Macedo Costa: Bispo do Pará. Secult.

Machado, L. O. (1997). Movimento de dinheiro e tráfico de drogas na Amazônia. In M. de M. Ribeiro, \& S. D. Seibel (Eds.). Drogas: Hegemonia do cinismo (pp. 217-242). Fundação Memorial da América Latina.

Magni, C. T. (2006). Nomadismo urbano: Uma etnografia sobre moradores de rua em Porto Alegre. Edunisc.

Malone, D. K., Collins, S. E., \& Clifasefi, S. L. (2015). Single-site housing first for chronically homeless people. Housing, Care and Support, 18(2), 62-66. https://doi.org/10.1108/HCS-05-2015-0007

Marinho, A. V. R., Saraiva, J. S., \& Rodrigues, J. E. C. (2015). Caracterização socioambiental da bacia urbana do Tucunduba, Belém-PA. Revista do Instituto Histórico e Geográfico do Pará, 2(2), 96-107. https://doi.org/10.17553/2359-0831/ihgp.v2n2p96-107

Marshall, T. H. (1967). Política social. Zahar Editores.

Mata, S., \& Fernandes, L. (2019). Revisitação aos atores e territórios psicotrópicos do Porto: Olhares etnográficos no espaço de 20 anos. Civitas: Revista de Ciências Sociais, 19(1), 195-212. https://doi.org/10.15448/1984-7289.2019.1.30648

McNamara, R. H. (2008). Homelessness in America. ABC-CLIO.

McNamara, R. H., Crawford, C., \& Burns, R. G. (2013). Policing the homeless: Policy, practice, and perceptions. 
Policing: An International Journal of Police Strategies \& Management, 36(2), 357-374. https://doi.org/10.1108/13639511311329741

Medeiros, R. de P. (2019). Entre as andanças e as travessias nas ruas da cidade: Territórios e uso de drogas pelos moradores de rua. Civitas: Revista de Ciências Sociais, 19(1), 142-158. https://doi.org/10.15448/1984-7289.2019.1.30759

Mendonça, T. (2014). Batan: Tráfico, milícia e “pacificação” na Zona Oeste do Rio de Janeiro [Unpublished mater's thesis]. Universidade Federal do Rio de Janeiro, Rio de Janeiro, Brasil.

Miranda, C. S., Beltrão, J. F., Henrique, M. C., \& Bessa, B. T. (2015). Santa Casa de Misericórdia e as políticas higienistas em Belém do Pará no final do século XIX. História, Ciências, Saúde-Manguinhos, 22(2), 525-539. https://doi.org/10.1590/S0104-59702015005000006

Muggleton, T. H. (2013). Public libraries and difficulties with targeting the homeless. Library Review, 62(1-2), 7-18. https://doi.org/10.1108/00242531311328113

Naim, M. (2006). Ilícito: O ataque da pirataria, da lavagem de dinheiro e do tráfico à economia global. Jorge Zahar Editor.

Natalino, M. A. C. (2016). Estimativa da população em situação de rua no Brasil. [Discussion Text 2246]. Ipea.

Nunes, D. S. (2016). Controle social e as práticas de 'justiçamento' pela sociedade civil no Brasil. Anais do XIII Seminário Internacional Demandas Sociais e Políticas Públicas na Sociedade Contemporânea. Edunisc. Retrieved from https://online.unisc.br/acadnet/anais/index.php/sidspp/article/view/16122/4013

Oh, H., \& Albertson, S. (2014). Don't walk by: Urban faith-based homeless outreach campaigns. Housing, Care and Support, 17(2), 111-115. https://doi.org/10.1108/HCS-03-2014-0006

Oliveira, I. B. de (2003). "Fora da higiene não há salvação": A disciplinarização do corpo pelo discurso médico no Brasil Republicano. Mneme: Revista de Humanidades, 4(7), 14-29.

Pacheco, T. do S. C. (2018). A história de crianças que viveram o isolamento compulsório no Educandário Eunice Weaver em Belém do Pará (1942-1980). Arquivo Brasileiro de Educação, 6(14), 181-215. https://doi.org/10.5752/P.2318-7344.2018v6n14p181-215

Pimenta, M. de M. (2019). Pessoas em situação de rua em Porto Alegre: Processos de estigmatização e invisibilidade social. Civitas: Revista de Ciências Sociais, 19(1), 82-104. https://doi.org/10.15448/1984-7289.2019.1.30905

Pinheiro, W. da C. (2017). O Instituto Orfanológico do Outeiro: Assistência, proteção e educação de meninos órfãos e desvalidos em Belém do Pará (1903-1913) [Unpublished doctoral dissertation]. Universidade Federal do Pará, Belém, PA, Brasil.

Pinho, L. B. de, Oliveira, I. R., Cardozo Gonzáles, R. I., \& Harter, J. (2012). Consumo de crack: Repercussões na estrutura e na dinâmica das relações familiares. Enfermería Global, 11(1), 150-160. https://doi.org/10.6018/eglobal.11.1.128361

Ramiro, F. de S., Padovani, R. da C., \& Tucci, A. M. (2014). Consumo de crack a partir das perspectivas de gênero e vulnerabilidade: Uma revisão sobre o fenômeno. Saúde em Debate, 38(101), 379-392. https://doi.org/10.5935/0103-1104.20140035

Santos, B. de S. (2003). Poderá o direito ser emancipatório? Revista Crítica de Ciências Sociais, 65(1), 3-76. https://doi.org/10.4000/rccs. 1180

Teasdale, S. (2010). Models of social enterprise in the homelessness field. Social Enterprise Journal, 6(1), 23-34. https://doi.org/10.1108/17508611011043039

Venancio, A. T. A. (2004). Doença mental, raça e sexualidade nas teorias psiquiátricas de Juliano Moreira. Physis: Revista de Saúde Coletiva, 14(2), 283-305. https://doi.org/10.1590/S0103-73312004000200006

Waldmann, P. (2006). El Estado anómico: Derecho, seguridad pública y vida cotidiana en América Latina. Iberoamericana Vervuert. https://doi.org/10.31819/9783964565594

Walker, S., \& Katz, C. M. (2008). The police in America: An introduction. (6th ed.). McGraw-Hill.

Wharne, S. (2015). Do people choose to be homeless? An existentially informed hermeneutic phenomenological analysis. Housing, Care and Support, 18(3-4), 101-112. https://doi.org/10.1108/HCS-07-2015-0013

Williams, R. (1973). The country and the city. Oxford University Press. 


\section{Notes}

Note 1. At the time the territory that today is Pará state was called the Providence of Grão-Pará.

Note 2. Antonio Lemos was public administer who held a position equivalent to what would be a present-day mayor (intendente).

\section{Copyrights}

Copyright for this article is retained by the author(s), with first publication rights granted to the journal.

This is an open-access article distributed under the terms and conditions of the Creative Commons Attribution license which permits unrestricted use, distribution, and reproduction in any medium, provided the original work is properly cited. 